dystrophy, joined by its international counterpart, United Parent Projects Muscular Dystrophy, filed an amicus curiae brief with the appellate court in support of PTC's position on the appeal. In addition, an amicus curiae brief supporting PTC was filed by the family of a boy with muscular dystrophy. This support from the patient community results from PTC's long-standing efforts to engage clinicians, regulators and patient advocates in the development of PTC124, in the belief that an open and direct approach to patient communications is in the best interests of all stakeholders. It is this openness that is threatened by the lower court's decision.
Note added in proof: On December 16, 2008, in a 3-0 decision, the Third Circuit Court of Appeals vacated the lower court's order, finding that there was no clear promise made to the Gunvalsons and thus no basis for their reliance. This is an important ruling for all companies conducting clinical trials in the area of rare or orphan diseases.

\section{COMPETING INTERESTS STATEMENT}

The author declares competing financial interest: details accompany the full-text HTML version of the paper at http://www.nature.com/naturebiotechnology/.

\section{Stuart W Peltz}

PTC Therapeutics, 100 Corporate Court, South Plainfield, New Jersey 07080, USA.

e-mail:speltz@ptcbio.com

1. Allison, M. Nat. Biotechnol. 26, 1201-1202 (2009).

\title{
DNA sequence patents are not in the grave yet
}

\author{
To the Editor: \\ his premature obituary. We \\ believe the patent article \\ by Miles Yamanaka ${ }^{1}$ in \\ the October issue entitled \\ "A nail in the coffin of \\ DNA sequence patents?" \\ is unduly alarmist. \\ The headline and final \\ sentence both imply that \\ the decision by the Board \\ of Patent Appeals and \\ Interferences (BPAI) on \\ the patent application
}

Some DNA sequence patent holders may be feeling like Mark Twain when he read of Kubin and Goodwin

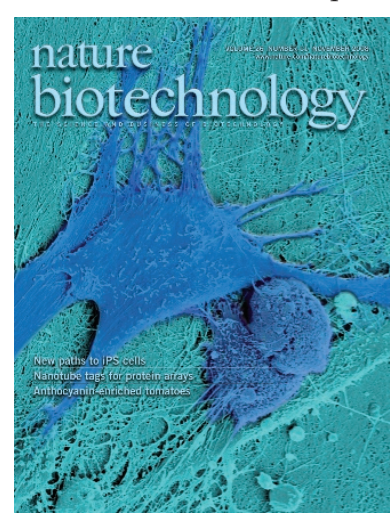

Court of Appeals for the Federal Circuit unwisely rendered largely inoperable for DNA sequence patents in its 1995 Deuel (application no. 09/667,859) threatens all DNA sequence patents. This is misleading because it is overly broad. In Kubin, the BPAI does suggest a higher standard for nonobviousness ${ }^{2}$, a criterion that the US protein's amino acid sequence. On that reading, Kubin merely captures a judgment that deriving a nucleic acid sequence from a corresponding amino acid sequence is straightforward to those with ordinary skill in the art, despite some degeneracy of the genetic code. (Yamanaka acknowledges the possibility of this narrow reading when he states "the Kubin decision will make it harder to obtain claims to a polynucleotide encoding a protein when that encoded protein is already known" [emphasis added].) But claims to DNA sequence derived from amino acid sequence are mainly confined to some 'first generation' gene patents based on cloning genes for known proteins. Most DNA sequence patents that we study in our work, for example, are not based on prior characterization of a protein, but start from a genetic discovery or DNA sequence variation.

Even if Kubin is read more broadly, to render invalid all composition of matter claims to DNA sequence patents where the procedure for finding the sequence is obvious to the ordinary genomic scientist, the case should not affect claims to inventions identified by procedures that are not obvious at the time of patent application. Kubin does not call into question patents on DNA sequences that arise from genuine invention; rather it corrects the anomalously low threshold for nonobviousness established by Deuel. Kubin is not a "nail in the coffin of DNA sequence patents," but rather a mechanism for culling marginal patents based on an accurate reading of the state of the science.

\footnotetext{
Robert Cook-Deegan ${ }^{1} \&$ Arti K Rai ${ }^{2}$

${ }^{1}$ Center for Genome Ethics, Law \& Policy, Institute for Genome Sciences \& Policy, Duke University, Box 90141, Durham, North Carolina 27708, USA. ${ }^{2}$ Elvin R. Latty Professor of Law, Duke Law School, Science Drive and Towerview Road, Durham, North Carolina 27708, USA. e-mail:bob.cd@duke.edu

1. Yamanaka, M. Nat. Biotechnol. 26, 1085-1086 (2008).

2. Ex parte Kubin, 83 USPQ2d 1410 (Bd. Pat. App. \& Int. 2007).
}

3. In re Deuel, 51 F.3d 1552 (Fed. Cir. 1995). 